\title{
POTENSI KONSORSIUM BAKTERI PEMACU PERTUMBUHAN SEBAGAI BAHAN AKTIF PUPUK ORGANIK HAYATI PADA TANAMAN JAGUNG
}

\author{
Yun Sondang ${ }^{1}$, Khazy Anty ${ }^{2}$, dan Ramond Siregar ${ }^{3}$ \\ ${ }^{1,2}$ Program Studi Budi Daya Tanaman Pangan, Jurusan Budi Daya Tanaman Pangan, \\ Politeknik Pertanian Negeri Payakumbuh, Sumatera Barat \\ ${ }^{3}$ Program Studi Paramedik Veteriner, Jurusan Budi Daya Tanaman Pangan, Politeknik Pertanian Negeri \\ Payakumbuh, J1. Raya Negara Km. 7 Tanjung Pati, Kecamatan Harau, Kabupaten Limapuluh Kota, \\ Sumatera Barat, Kode Pos: 26271 \\ e-mail: silitongayun27@gmail.com
}

Diserahkan: 22 Oktober $2020 \quad$ Diterima: 7 Desember 2020

\begin{abstract}
The purpose of this research are to determine the potential of consortium of plant growthpromoting bacteria as an active ingredients of bio-organic fertilizers and to determine the effect of bio-organic fertilizers on growth and production of maize. The research was carried out at the Politeknik Pertanian Negeri Payakumbuh Experimental Field, Limapuluh Kota Regency, West Sumatra in March-July 2020. The research was starting with the manufacture of water hyacinth bio-organic fertilizer (POH) which inoculated with a consortium of bacteria from the genera Pseudomonas and Bacillus. POH observations were carried out on species, population size, and nutrient content of bio-organic fertilizers. The POH application research was using a factorial design in a randomized block design with treatment I at POH 40,80,120, $160 \mathrm{ml} / \mathrm{l}$ water and treatment II with frequency of 2, 3, 4 times giving $P O H$. The variables observed were $N, P, K$ nutrient content, plant dry weight, and dry maize seed production. The results of the POH study contained $P$. aeruginosa, B. subtilis, and B. cereus with a total population of $2,8,10^{7}-2,8,10^{8}$, potentially as active ingredients for bio-organic fertilizers. $\mathrm{POH}$ water hyacinth can increase plant $N, P, K$ nutrients, plant dry weight, and dry maize seed production. The optimal POH dose for all observed variables is $80 \mathrm{ml} / \mathrm{l}$ of water.
\end{abstract}

Keywords: bacteria consortium, bio-organic fertilizers, P. aeruginosa, maize

\section{PENDAHULUAN}

Pada saat ini penggunaan pupuk anorganik dapat ditingkatkan efisiensinya dengan penambahan pupuk organik. Penggunaan pupuk anorganik secara tunggal mempunyai beberapa kelemahan antara lain dampak negatif residu pupuk terhadap kualitas hasil panen, kualitas tanah dan lingkungan. Solusinya penggunaan pupuk anorganik dikurangi secara perlahan dan beralih kepada penggunaan pupuk organik hayati yang relatif aman. Keuntungan penggunaan pupuk organik hayati selain sebagai biofertilizer juga berperan sebagai biokontrol dan biostimulan. Salah satu teknologi peningkatan produksi tanaman yang efektif adalah penggunaan pupuk hayati secara langsung pada benih dan tanaman. Menurut Jacoby et al. (2017) pupuk hayati adalah produk yang diformulasikan mengandung satu atau lebih mikroorganisme yang dapat meningkatkan status hara tanaman baik dengan mengganti unsur hara tanah dan atau dengan membuat unsur hara lebih banyak tersedia bagi tanaman dan atau dengan 
meningkatkan hubungan tanaman dengan mikroorganisme.

Pemanfaatan mikroorganisme dalam pembuatan pupuk organik mulai sering diteliti. Bakteri menguntungkan berperan dalam mendekomposisi bahan organik dan menyediakan hara bagi tanaman. Pam et al. (2012) menyatakan bahwa mikroorganisme yang diinokulasi ke dalam pupuk organik bertujuan untuk memanfaatkan kemampuan mikroba dalam perannya sebagai dekomposer. Pemanfaatan mikroorganisme sebagai pupuk hayati dapat mengurangi dosis pupuk anorganik (Chen, 2006) ; Supriyo $d k k$. (2014), meningkatkan hara yang dapat diserap dari tanah, meningkatkan produktivitas tanaman, dan meningkatkan kualitas lahan secara berkelanjutan (Kumawat et al. 2017).

Peran multifungsi bakteri sebagai pemacu pertumbuhan tanaman (PGPR), pupuk hayati, dan penekan penyakit tanaman berpotensial dalam pengembangan sistem produksi tanaman berkelanjutan (Yasmin et al. 2016) ; (Vejan et al. (2016). PGPR mendiami akar tanaman dan memberikan efek positif mulai dari mekanisme pengaruh langsung hingga efek tidak langsung (Vejan et al. (2016). PGPR dapat mendukung kesehatan tanaman dengan meningkatkan kesuburan tanah, meningkatkan ketersediaan nutrisi dan penyerapannya (Nehra et al. 2016).

Penelitian ini bertujuan untuk mengetahui potensi konsorsium bakteri pemacu pertumbuhan tanaman sebagai bahan aktif pembuatan pupuk organik hayati $(\mathrm{POH})$ dan melihat pengaruh $\mathrm{POH}$ terhadap pertumbuhan dan produksi jagung.

\section{METODEOLOGI PENELITIAN}

Penelitian dilaksanakan di Kebun Percobaan Politeknik Pertanian Negeri Payakumbuh Sumatera Barat dari bulan Maret-Juli 2020 pada ketinggian $500 \mathrm{~m}$ di atas permukaan laut.

Bahan yang digunakan kotoran kandang sapi, eceng gondok, sumber kalsium, benih Pioneer 21, pupuk Urea, SP36, KCl, de Man Rogosa Sharpe agar (MRS agar), dan koleksi bakteri hasil penelitian PDUPT tahun I dana Ristek Dikti (Sondang $d k k$. 2019b).

Pembuatan pupuk organik hayati dengan bahan utama kotoran kandang sapi dan eceng gondok, lalu ditambahkan sumber kalsium dan diinokulasi dengan konsorsium bakteri 6 spesies dari genera Pseudomonas spp. dan Bacillus sp. Hasil fermentasi pupuk organik hayati yang digunakan dalam aplikasi terhadap benih dan tanaman jagung. Kandungan hara N, $\mathrm{P}, \mathrm{K}, \mathrm{C}$-organik, $\mathrm{Ca}, \mathrm{pH}$ dari $\mathrm{POH}$ eceng gondok hasil fermentasi dianalisis dengan metode yang sesuai.

Bakteri di dalam $\mathrm{POH}$ eceng gondok diisolasi dan diidentifikasi berdasarkan bentuk koloni, bentuk tepi, permukaan, halus kasar permukaan, warna permukaan, warna pigmen, dan kepekatan tubuh bakteri. Dilanjutkan dengan identifikasi bakteri menggunakan analisis molekuler berdasarkan runutan gen 16S rRNA menggunakan PCR.

Penghitungan jumlah populasi bakteri dilakukan dengan cara mengambil $1 \mathrm{ml}$ larutan 
pupuk hayati dimasukkan ke dalam tabung reaksi yang berisi $9 \mathrm{ml}$ aquades steril, dan dihomogenkan (diberi kode pengenceran $10^{-1}$ ). Selanjutnya dibuat pengenceran berseri sampai $10^{-7}$. Suspensi dari pengenceran $10^{-1}-10^{-7}$ diambil sebanyak $200 \mu 1$ menggunakan pipet mikro dan dimasukkan dalam cawan petri yang telah berisi media padat MRS agar. Cawan petri selanjutnya diinkubasi pada suhu ruang selama 24-48 jam. Koloni bakteri yang tumbuh pada permukaan media dihitung, dan jumlah bakteri diperoleh dengan cara jumlah koloni bakteri yang tumbuh dikalikan 10 kemudian dikalikan lagi dengan faktor pengenceran dengan rumus: jumlah koloni $\mathrm{CFU} / \mathrm{ml}=$ jumlah koloni $\mathrm{x} 10 \times \mathrm{x}$ faktor pengenceran

Penelitian aplikasi $\mathrm{POH}$ pada tanaman jagung dilaksanakan menggunakan percobaan Faktorial yang disusun secara Rancangan Acak Kelompok (RAK) yang terdiri dari 2 faktor perlakuan dengan 3 kali ulangan. Faktor pertama adalah takaran POH $40 \mathrm{ml}, 80 \mathrm{ml}, 120$ ml, $160 \mathrm{ml}$ per liter air. Faktor kedua adalah frekuensi 2, 3, 4 kali pemberian. Benih yang akan ditanam terlebih dahulu direndam dalam larutan $\mathrm{POH} 10 \%$ selama 12 jam. Benih jagung ditanam 1 biji per lubang tanam dengan pupuk anorganik $1 / 2$ dosis rekomendasi. $\mathrm{POH}$ cair disemprotkan pada daun tanaman saat umur 14, 28, 42, 56 hari setelah tanam sesuai perlakuan.

Pengamatan tanaman jagung dilakukan terhadap kandungan hara $\mathrm{N}, \mathrm{P}, \mathrm{K}$ tanaman pada akhir masa vegetatif, berat kering tanaman, dan produksi pipilan kering jagung. Data dianalisis sidik ragam dan uji lanjutan LSD pada taraf nyata $5 \%$.

\section{HASIL dan PEMBAHASAN}

\section{Spesies Bakteri dan Karakteristik POH}

Ditemukan 3 spesies bakteri yang dominan dalam $\mathrm{POH}$ cair eceng gondok dengan jumlah populasi $>10^{7} \mathrm{CFU} / \mathrm{ml}$. Ketiga bakteri termasuk genera Pseudomonas spp. dan Bacillus sp. seperti terlihat pada Tabel 1.

Tabel 1. Spesies bakteri, jumlah populasi dan peran bakteri dalam $\mathrm{POH}$

\begin{tabular}{|c|c|c|}
\hline Spesies Bakteri & $\begin{array}{l}\text { Jumlah } \\
\text { Populasi }\end{array}$ & Peran Bakteri \\
\hline Pseudomonas & $2,8 \times 10^{8}$ & Penambat $\mathrm{N}$, \\
\hline aeruginosa & $\mathrm{CFU} / \mathrm{ml}$ & $\begin{array}{l}\text { pelarut } \mathrm{P} \text {, bakteri } \\
\text { antagonis, } \mathrm{PGPR}\end{array}$ \\
\hline Bacillus subtilis & $\begin{array}{c}4,3 \times 10^{7} \\
\mathrm{CFU} / \mathrm{ml}\end{array}$ & $\begin{array}{l}\text { Penambat } \mathrm{N} \text {, } \\
\text { pelarut } \mathrm{P}, \\
\text { produksi IAA, } \\
\text { bakteri antagonis, } \\
\text { biokontrol }\end{array}$ \\
\hline Bacillus cereus & $\begin{array}{c}2,8 \times 10^{7} \\
\mathrm{CFU} / \mathrm{ml}\end{array}$ & $\begin{array}{l}\text { Penambat } \mathrm{N} \text { non- } \\
\text { simbiotik, } \\
\text { produksi } \\
\text { fitohormon, } \\
\text { bakteri antagonis }\end{array}$ \\
\hline
\end{tabular}

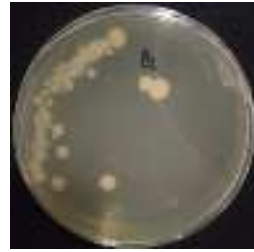

P. aeruginosa

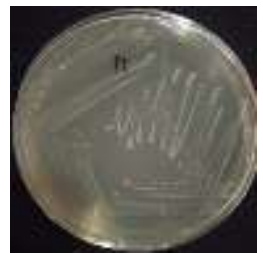

B. subtilis

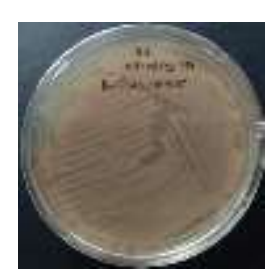

B. cereus
Pada Tabel 1 P. aeruginosa merupakan bakteri paling dominan di dalam $\mathrm{POH}$ cair dengan jumlah populasi $2,8 \times 10^{8} \mathrm{CFU} / \mathrm{ml}$. Bakteri ini tergolong bakteri nonsimbiosis yang mampu mengikat $\mathrm{N}$ dan $\mathrm{P}$, sehingga bakteri ini mampu bertahan dan bersaing dengan mikroba lainnya. Sandilya et al. (2017) menyatakan bakteri $P$. aeruginosa dapat berperan sebagai PGPR dengan mekanisme 
sintesis $\mathrm{NH}_{3}, \mathrm{HCN}$, dan senyawa sideropor. Penelitian Parani and Saha (2012) menunjukkan bakteri dari strain Pseudomonas spp. dapat meningkatkan pertumbuhan dan perkembangan tanaman yang disebabkan peningkatan serapan hara $\mathrm{P}$ oleh tanaman dan sumbangan perangsang tumbuh $\mathrm{GA}_{3}$.

Hasil penelitian sebelumnya menyatakan $B$. subtilis termasuk bakteri penambat $\mathrm{N}$ nonsimbiotik yang bersifat fakultatif. Genera Bacillus merupakan bakteri gram positif yang membentuk endospore dan berkemampuan menghasilkan berbagai peptida bioaktif (Sabate and Audisio, 2011). Metabolitnya menunjukkan sifat antagonis sehingga digunakan untuk melawan patogen. Kumawat, et al. (2017) melaporkan sebagian besar genera Bacillus sp. dapat dijadikan pupuk hayati karena kemampuan bakteri ini dalam melarutkan fosfat, bahkan spesies tertentu dapat melarutkan hara mikro $\mathrm{Zn}$ dan Si.

Bakteri B. cereus adalah salah satu bakteri nonpatogen yang berasal dari tanaman dan bersifat tidak merusak tanaman inang. $B$. cereus meningkatkan prolin, enzim antioksidan, fitohormon dan komponen hasil (Hassan et al. 2018). Bakteri merupakan salah satu agen non-patogen pada tanaman yang berpotensi sebagai pengendali biologis (Arfarita et al. 2019).

Bakteri sebagai mahluk hidup membutuhkan lingkungan yang sesuai untuk tumbuh berkembang, sehingga bakteri yang kuat adalah bakteri yang mampu bertahan dalam kondisi yang tidak menguntungkan.
Ketiga bakteri di atas merupakan bakteri yang kuat, mampu bertahan dan bersaing dengan mikroba lainnya. Spesies dan jumlah populasi bakteri di dalam produk pupuk hayati bervariasi tergantung dari bahan baku dalam memproduksi pupuk organik hayati. Bakteri dapat hidup dan berkembang dari bahan organik (sumber karbon) pada media tempat tumbuhnya. Berdasarkan pembuatannya, $\mathrm{POH}$ memenuhi persyaratan kerapatan mikroba, sehingga bakteri ini dapat digunakan sebagai bahan aktif pupuk hayati. Bakteri mempunyai peran ganda, yaitu mendekomposisi bahan organik dan memineralisasi hara. Ketiga jenis bakteri memiliki sifat kompatibilitas yang saling mendukung dalam peranannya sebagai dekomposer bahan organik (kotoran kandang sapi dan eceng gondok), sehingga dikelompokkan ke dalam mikroba Fungsional dengan kriteria jumlah populasi $\geq 1 \times 10^{5}$ (Balai Penelitian Tanah, 2018).

Hasil dekomposisi bahan organik yang diinokulasi konsorsium bakteri menghasilkan karakteristik kimia seperti pada Tabel 2.

Tabel 2. Karakteristik kimia POH eceng gondok

\begin{tabular}{lc}
\hline Komponen hara & Kandungan kimia \\
\hline $\mathrm{N}$ total (\%) & 2,21 \\
$\mathrm{P}_{2} \mathrm{O}_{5}(\%)$ & 1,90 \\
$\mathrm{~K}_{2} \mathrm{O}(\%)$ & 1,13 \\
$\mathrm{C}-$ organik (\%) & 37,5 \\
$\mathrm{Ca}(\%)$ & 0,259 \\
$\mathrm{C} / \mathrm{N}$ & 16,97 \\
$\mathrm{pH}$ & 6,1 \\
\hline \multicolumn{2}{c}{ Karakteristik kimia $\mathrm{POH}$ sangat } \\
dipengaruhi oleh jumlah populasi dan \\
kemampuan bakteri dalam mendegradasi \\
bahan organik, serta kemampuan beradaptasi
\end{tabular}


dengan kondisi lingkungan ruang fermentasi. Pada fermentasi eceng gondok spesies Bacillus sp. berperan besar dalam mendegradasi selulosa, sehingga disebut bakteri selulolitik. Kandungan $\mathrm{N}$ dari $\mathrm{POH}$ yang agak tinggi mengindikasikan genera Bacillus sp. mempunyai kemampuan mengikat $\mathrm{N}$ tanpa bantuan tanaman inang. Ahmad et al. (2018) menyatakan beberapa genera Bacillus memiliki kemampuan mengikat $\mathrm{N}$ dari udara, melarutkan $\mathrm{P}$ dan $\mathrm{K}$, menghasilkan zat pemacu pertumbuhan, dan menekan pertumbuhan patogen penyebab penyakit.

Bakteri pemacu pertumbuhan tanaman merupakan bakteri yang dapat meningkatkan pertumbuhan tanaman dan melindungi tanaman dari penyakit melalui berbagai mekanisme (Souza et al. 2015). Etesami et al. (2017) ; Kumawat et al. (2017) menyatakan beberapa spesies bakteri Bacillus dapat melarutkan mineral silikat dan melepaskan hara $\mathrm{K}$ dalam bentuk asam organik dan anorganik. Sehingga pupuk hayati yang mengandung bakteri pelarut $\mathrm{K}$ dapat digunakan sebagai pengganti pupuk anorganik. Sekresi berupa asam organik menurunkan $\mathrm{pH}$ tanah dan membantu melarutkan $\mathrm{P}$ yang terikat koloid tanah (Kumawat et al. 2017).

\section{Kandungan Hara N, P, K Tanaman Jagung}

Terjadi interaksi antara takaran $\mathrm{POH}$ dengan frekuensi pemberian $\mathrm{POH}$ terhadap kandungan hara $\mathrm{N}, \mathrm{P}$, dan $\mathrm{K}$ tanaman jagung. Pemberian $\mathrm{POH}$ yang diinokulasi bakteri dapat meningkatkan kandungan $\mathrm{N}, \mathrm{P}$, dan $\mathrm{K}$ jagung (Tabel 3), hal ini disebabkan kemampuan masing-masing bakteri dalam perannya sebagai pengikat $\mathrm{N}$, maupun sebagai pelarut $\mathrm{P}$ dan K. Khusus untuk hara N, ada kecenderungan peningkatan hara $\mathrm{N}$ tanaman dengan semakin meningkatnya takaran $\mathrm{POH}$ yang diberikan.

Tabel 3. Kandungan hara N, P, dan K tanaman jagung pada berbagai takaran dan frekuensi pemberian $\mathrm{POH}$

\begin{tabular}{|c|c|c|c|}
\hline \multirow{2}{*}{ Takaran $\mathrm{POH}$} & \multicolumn{3}{|c|}{ Hara $\mathrm{N}$ tanaman jagung (\%) } \\
\hline & 2 kali & 3 kali & 4 kali \\
\hline $40 \mathrm{ml}$ & $2,997^{\mathrm{cd}}$ & $2,993^{\mathrm{d}}$ & $3,023^{a b}$ \\
\hline $80 \mathrm{ml}$ & $3,023^{a b}$ & $3,000^{\mathrm{cd}}$ & $3,043^{\mathrm{a}}$ \\
\hline $120 \mathrm{ml}$ & $3,027^{a b}$ & $3,027^{a b}$ & $2,997^{\mathrm{b}}$ \\
\hline $160 \mathrm{ml}$ & $3,017^{a}$ & $3.017^{\mathrm{a}}$ & $3.043^{\mathrm{a}}$ \\
\hline \multirow{2}{*}{ Takaran $\mathrm{POH}$} & \multicolumn{3}{|c|}{ Hara P tanaman jagung (\%) } \\
\hline & 2 kali & 3 kali & 4 kali \\
\hline $40 \mathrm{ml}$ & $0,286^{\mathrm{bc}}$ & $0,283^{\text {bcd }}$ & $0,298^{a}$ \\
\hline $80 \mathrm{ml}$ & $0,283^{\mathrm{bcd}}$ & $0,276^{\mathrm{cd}}$ & $0,296^{a}$ \\
\hline $120 \mathrm{ml}$ & $0,288^{a b}$ & $0,288^{b}$ & 0,259 e \\
\hline $160 \mathrm{ml}$ & $0,290^{\mathrm{ab}}$ & $0,284^{b c}$ & $0,274^{\mathrm{d}}$ \\
\hline \multirow{2}{*}{ Takaran $\mathrm{POH}$} & \multicolumn{3}{|c|}{ Hara K tanaman jagung (\%) } \\
\hline & 2 kali & 3 kali & 4 kali \\
\hline $40 \mathrm{ml}$ & $1,313^{\mathrm{e}}$ & $1,410^{\mathrm{bcd}}$ & $1,483^{a b}$ \\
\hline $80 \mathrm{ml}$ & $1,530^{\mathrm{a}}$ & $1,430^{\mathrm{bcd}}$ & $1,503 \mathrm{bcd}$ \\
\hline $120 \mathrm{ml}$ & $1,527^{\mathrm{a}}$ & 1,373 cde & $1,457^{a b c}$ \\
\hline $160 \mathrm{ml}$ & $1,373^{\text {cde }}$ & $1,360 \mathrm{de}$ & $1,347 \mathrm{de}$ \\
\hline
\end{tabular}

Angka-angka yang diikuti huruf kecil yang sama pada kolom yang sama, berbeda tidak nyata berdasarkan uji LSD pada taraf nyata $5 \%$.

Bakteri penambat $\mathrm{N}$ memiliki peranan penting dalam pertumbuhan tanaman, karena fungsinya sebagai penyedia hara nitrogen, terutama dalam bentuk $\mathrm{NH}_{4}{ }^{+}$dan $\mathrm{NO}^{-}$yang dapat digunakan untuk proses metabolisme tanaman. Hara N, P dan $\mathrm{K}$ yang tertinggi terdapat pada takaran POH $80 \mathrm{ml} / \mathrm{l}$ air (Tabel 3). Hassan et al. (2018) menyatakan bioinokulasi $B$. cereus dapat meningkatkan NO3-N, P, K, dan bahan organik. Hasil penelitian Sondang et al. (2019a) pupuk kompos yang diinokulasi dengan mikroorganisme indigenus meningkatkan serapan hara $\mathrm{P}$ dan $\mathrm{K}$ tanaman jagung. Menurut Souza et al. (2015); Vejan et al. 
(2016) bakteri berpengaruh secara tidak langsung terhadap tanaman melalui perannya sebagai pemacu pertumbuhan tanaman, dengan mekanisme pengikatan $\mathrm{N}$, pelarutan $\mathrm{P}$ dan K, produksi Siderofor, produksi fitohormon dalam bentuk IAA.

\section{Berat Kering Tanaman Jagung}

Berat kering tanaman jagung menggambarkan pertumbuhan tanaman secara keseluruhan dapat dilihat pada Tabel 4.

Tabel 4. Berat kering tanaman jagung pada berbagai takaran dan frekuensi pemberian $\mathrm{POH}$

\begin{tabular}{lccc}
\hline \multirow{2}{*}{ Takaran POH } & \multicolumn{3}{c}{ Frekuensi Pemberian POH } \\
\cline { 2 - 4 } & 2 kali & 3 kali & 4 kali \\
\hline $40 \mathrm{ml}$ & $325,7^{\mathrm{i}}$ & $368,3^{\mathrm{h}}$ & $461,7^{\mathrm{g}}$ \\
$80 \mathrm{ml}$ & $457,0^{\mathrm{g}}$ & $487,0^{\mathrm{fg}}$ & $532,7^{\mathrm{e}}$ \\
$120 \mathrm{ml}$ & $520,7^{\text {ef }}$ & $582,7^{\mathrm{d}}$ & $636,7^{\mathrm{c}}$ \\
$160 \mathrm{ml}$ & $714,7^{\mathrm{b}}$ & $652,3^{\mathrm{c}}$ & $764,0^{\mathrm{a}}$ \\
\hline
\end{tabular}

Angka-angka yang diikuti huruf kecil yang sama pada kolom yang sama, berbeda tidak nyata berdasarkan uji LSD pada taraf nyata $5 \%$

Peningkatan unsur hara $\mathrm{N}, \mathrm{P}$, dan $\mathrm{K}$ akan merangsang pertumbuhan organ-organ vegetatif tanaman. Tanaman yang kebutuhan hara nitrogennya tercukupi akan membentuk tanaman dengan ukuran optimal. Tabel 4 memperlihatkan kecenderungan semakin tinggi takaran $\mathrm{POH}$ dan frekuensi pemberiannya akan meningkatkan berat kering tanaman jagung. $\mathrm{POH}$ yang mengandung bakteri pemacu pertumbuhan meningkatkan jumlah dan ukuran daun, memperbesar diameter batang, meningkatkan panjang akar tanaman, sehingga berat berangkasan tanaman juga akan meningkat. Disini peran bakteri sebagai pemacu pertumbuhan akan mengatur keseimbangan nutrisi dan pelarutan hara. Hal ini diperkuat penyataan Vejan et al. (2016) bahwa mekanisme PGPR mengatur keseimbangan hormonal dan nutrisi. Sandilya et al. (2017) menyatakan bioformulasi $P$. aeruginosa sebagai pupuk berperan dalam meningkatkan biomassa daun dan akar tanaman jarak. Penelitian Wong et al. (2015) menemukan fitohormon yang dihasilkan oleh pupuk hayati memacu pertumbuhan dan perkembangan tanaman dengan cara mengontrol regulasi pada proses proliferasi sel, dan sumbangan nutrisi dalam bentuk mineral dari pupuk hayati.

\section{Produksi Pipilan Kering Jagung}

Aktivitas bakteri dapat meningkatkan pertumbuhan tanaman jagung melalui perannya sebagai penyedia hara bagi tanaman. Pemberian $\mathrm{POH}$ yang dilakukan beberapa kali akan menjamin ketersediaan hara setiap saat. Hara yang tersedia dari awal pertumbuhan sampai memasuki fase generatif akan mempengaruhi produksi pipilan jagung seperti terlihat pada Tabel 5 .

Tabel 5. Produksi pipilan kering jagung pada berbagai takaran dan frekuensi pemberian $\mathrm{POH}$

\begin{tabular}{lcccc}
\hline Takaran & \multicolumn{2}{c}{ Frekuensi Pemberian POH } & Rata- \\
\cline { 2 - 4 } POH & 2 kali & 3 kali & 4 kali & rata \\
\hline $40 \mathrm{ml}$ & $11,41^{\mathrm{ab}}$ & $11,74^{\mathrm{ab}}$ & $11,26^{\mathrm{ab}}$ & $11,47^{\mathrm{a}}$ \\
$80 \mathrm{ml}$ & $12,18^{\mathrm{a}}$ & $10,96^{\mathrm{ab}}$ & $11,66^{\mathrm{ab}}$ & $11,60^{\mathrm{a}}$ \\
$120 \mathrm{ml}$ & $10,47^{\mathrm{b}}$ & $11,86^{\mathrm{ab}}$ & $11,67^{\mathrm{ab}}$ & $11,33^{\mathrm{a}}$ \\
$160 \mathrm{ml}$ & $11,69^{\mathrm{ab}}$ & $12,46^{\mathrm{a}}$ & $12,29^{\mathrm{a}}$ & $12,15^{\mathrm{a}}$ \\
\hline Rata-rata & $11,44^{\mathrm{a}}$ & $11,76^{\mathrm{a}}$ & $11,72^{\mathrm{a}}$ & \\
\hline Angka-angka yang diikuti huruf kecil yang sama pada kolom \\
yang sama, berbeda tidak nyata berdasarkan uji LSD pada \\
taraf nyata 5\%
\end{tabular}

POH dengan berbagai takaran dan frekuensi pemberian berpengaruh tidak nyata terhadap produksi pipilan kering jagung. Hal ini disebabkan proses pemberian $\mathrm{POH}$ yang direndam ke benih dan disemprotkan langsung ke tanaman cukup memenuhi kebutuhan hara 
tanaman. Berdasarkan produksi pipilan kering jagung yang berhubungan dengan kandungan hara $\mathrm{N}, \mathrm{P}, \mathrm{K}$ tanaman, $\mathrm{POH}$ yang optimal diberi dengan takaran $80 \mathrm{ml} / \mathrm{l}$ air. Yasmin et al. (2016) menyatakan beberapa genera Pseudomonas spp. dan Bacillus sp. bersifat antagonis non-patogen, dapat meningkatkan pertumbuhan dan produksi melalui produksi asetat indol dan peningkatan aktivitas enzim katalase. Hasil penelitian Hassan et al. (2018) menunjukkan bahwa bioinokulasi $B$. cereus dapat meningkatkan prolin, enzim antioksidan, fitohormon dan komponen hasil, sehingga pertumbuhan dan produksi tanaman juga meningkat. Diperkuat dengan pernyataan Chen (2006) bahwa pemberian pupuk hayati yang diinokulasi dengan mikroorganisme dapat meningkatkan ketersediaan hara tanaman dan meningkatkan produktivitas tanaman.

\section{KESIMPULAN}

1. Pupuk organik yang diinokulasi dengan konsorsium bakteri pemacu pertumbuhan akan menghasilkan produk $\mathrm{POH}$ dengan bakteri yang sama. Sifat memacu pertumbuhan tanaman lebih disebabkan oleh kemampuan bakteri dalam menambat N, melarutkan hara P dan K. Ketiga bakteri P. aeruginosa, B. subtilis, dan B. cereus berpotensi sebagai bahan aktif pupuk organik hayati.

2. $\mathrm{POH}$ eceng gondok dapat meningkatkan kandungan hara $\mathrm{N}, \mathrm{P}, \mathrm{K}$, bobot kering tanaman, dan produksi biji kering jagung.
Takaran POH yang optimal terhadap semua variabel pengamatan adalah $80 \mathrm{ml} / \mathrm{l}$ air.

\section{UCAPAN TERIMA KASIH}

Terima kasih kepada Direktorat Riset dan Pengabdian Masyarakat, Kementerian Riset dan Teknologi yang telah mendanai penelitian ini dan terima kasih yang mendalam kepada Tuhan Yang Maha Esa sehingga penulis dapat menyelesaikan artikel dengan judul "Potensi Konsorsium Bakteri Pemacu Pertumbuhan sebagai Bahan Aktif Pupuk Organik Hayati pada Tanaman Jagung”. Semoga artikel ini bermanfaat bagi pembaca.

\section{DAFTAR PUSTAKA}

Ahmad, M., L. Pataczek, T.H. Hilger, Z.A. Zahir, A. Hussain, F. Rasche, R. Schafleitner, and S.Q. Solberg. 2018. Perspectives of Microbial Inoculation for Sustainable Development and Environmental Management. Jurnal Frontiers in Microbiology, 9 (2992) : 126. doi: 10.3389/fmicb.2018.02992.

Arfarita, N., Muhibuddin, A., and Imai, T. 2019. Exploration of Indigenous Free Nitrogen-Fixing Bacteria from Rhizosphere of Vigna radiata for Agricultural Land Treatment. Journal Degraded and Mining Lands Management. 6 (2) : 1617-1623. doi: 10.15243/jdmlm.2019.062. 1617.

Balai Penelitian Tanah. 2018. Syarat Mutu Pupuk An-organik dan Organik. Badan Penelitian dan Pengembangan Pertanian. Kementerian Pertanian, Jakarta. 23 hal.

Chen, J. H. 2006. The Combined Use of Chemical and Organic Fertilizers and or Biofertilizer for Crop Growth and Soil Fertility. International Workshop on Sustained Manajement of the SoilRhizosphere System for Efficient Crop Production and Fertilizer Use, 16-20 October 2006. Land Development Departement, Bangkok 10900 Thailand. 
Etesami, H., S. Emami, and H.A. Alikhani. 2017. Potassium Solubilizing Bakteri (KSB) Mechanisms Promotion of Plant Growth, and Futures Prospect-A Review. Journal of Soil Sciences and Plant Nutrition, 17 (4) : 897-911.

Hassan, T.U., A. Bano, I. Naz, and M. Hussain. 2018. Bacillus cereus: Acompetent Plant Growth Promoting Bacterium of Saline Sodic Field. Pakistan Journal of Botany, 50 (3) : 1029-1037.

Jacoby, R. M. Peukert, A. Succurro, A. Koprivova, and S. Kopriva. 2017. The Role of Soil Microorganisms in Plant Mineral Nutrition-Current Knowledge and Future Directions. Frontiers in Plant Science, 8 (1617) : 1-19, doi: 10.3389/fpls. 2017.01617.

Kumawat, N., S. Kumar, R. Kumar, and V.S. Meena. 2017 Nutrient Solubilizing Microbes (NSMs): Its Role in Sustainable Crop Production, 2 : 25-61. From book V.S. Meena et al. (eds.): Agriculturally Important Microbes for Sustainable Agriculture, Springer Nature Singapore Pte Ltd. doi: 10.1007/978981-10-5343-6_2.

Nehra, V., B.S. Sahara, and M. Choudhary. 2016. Evaluation of Brevibacillus brevis as a Potential Plant Growth Promoting Rhizobacteria for Cotton (Gossypium hirsutum) Crop. SpringerPlus, 5 (948). doi: 10.1186/s40064-016-2584-8.

Pam I., B. Dam, and S.K. Sen. 2012. Composting of Common Organic Wastes Using Microbial Inoculations. 3 Biotech, 2 (2) : 127-134. doi: 10.1007/ s13205-011-0033-5.

Parani, K. and B.K. Saha. 2012. Prospects of Using Phosphate Solubilizing of Pseudomonas as Bio-Fertilizer. European Journal of Biological Sciences, 4 (2) : 40-44.

Sabate, D.C. and M.C. Audisio. 2013. Inhibitory Activity of Surfactin, Produced by Different Bacillus subtilis subsp. Subtilis strains, Against Listeria Monocytogenes Sensitive and Bacteriocin-Resistant Strains.
Microbiological Research, 168 : 125129. doi: 10.1016/j.micres.2012. 11.004.

Sandilya, S.P., P.M. Bhuyan, V. Nageshappa, D.K. Gogoi, and D. Kardong. 2017. Impact of Pseudomonas aeruginosa NAJ PIA03 Affecting The Growth and Phytonutrient Production of Castor, A Primary Host-Plant of Samia ricini. Journal of Soil Science and Plant Nutrition, 17 (20) : 499-515.

Sondang, Y., K. Anty, and R. Siregar. 2019a. The Effect of Biofertilizer And Inorganic Fertilizer Toward the Nutrient Uptake in Maize Plant (Zea mays L.). Journal of Applied Agricultural Science and Technology, 3 (2) : 213-225. ISSN: 2621-2528.

Sondang, Y., R. Siregar, dan K. Anty. 2019b. Penerapan Pupuk Hayati dalam Meningkatkan Produksi Jagung (Zea mays L.) di Kabupaten Limapuluh Kota. Unri Conference Series: Community Engagement, 1 : 202-209. https:// doi.org/10.31258/unricsce.1. 202-209.

Souza, R., A. Ambrosini, and L.M.P. Passaqlia. 2015. Plant GrowthPromoting Bacteria as Inoculants in Agricultural Soils. Journal Genetics and Molecular Biology, 38 (4) : 401-419.

Supriyo, A., S. Minarsih, and B. Prayudi. 2014. Efektifitas Pemberian Pupuk Hayati Terhadap Pertumbuhan dan Hasil Padi Gogo pada Tanah Kering. Jurnal AGRITECH, XVI (1) : 1-12.

Vejan, P., Abdullah, R., Khadiran, T., Ismail, S., and Boyce, A.N. 2016. Role of Plant Growth Promoting Rhizobacteria in Agricultural Sustainability. Jurnal Molecules, 21 (573) : 1-17. doi: 10.3390/molecules21050573.

Wong, W.S., S.N. Tan, L. Ge, X. Chen, and J.W.H. Yong. 2015. The Importance of Phytohormones and Microbes in Biofertilizers. In: D.K. Maheshwari (ed.) Bacterial Metabolites in Sustainable Agroecosystem, Sustainable Development and Biodiversity, 12. doi:10.1007/ 978-3-319-24654-3_6, Springer International Publishing Switzerland. 
Yasmin S., A. Zaka, A. Imran, M.A. Zahid, S. Yousaf, G. Rasul, Arif, M. and M.S. Mirza. 2016. Plant Growth Promotion and Suppression of Bacterial Leaf Blight in Rice by Inoculated Bacteria. PLoS ONE, $11 \quad$ (8) : 1-19. doi: 10.1371/journal.pone. 0160688 . 